EDUKACJA MIĘDZYKULTUROWA

\title{
Wkład Kościoła ewangelickiego w kształtowanie otwartej tożsamości religijnej młodzieży zaolziańskiej
}

\begin{abstract}
Dopiero kiedy zrozumiemy, że potrzebujemy siebie nawzajem właśnie w swojej inności, możemy zaczać szukać praktycznych rozwiazań i dróg wyjścia $z$ wielu ślepych uliczek, w które wprowadziła nas nasza jednostronnośc ${ }^{1}$
\end{abstract}

Tomáš Halík

Streszczenie: Praca jest próbą spojrzenia na edukacyjną działalność Śląskiego Kościoła Ewangelickiego Augsburskiego Wyznania na Zaolziu w Republice Czeskiej - w kontekście jej zadań, odnoszących się do wspomagania kształtowania tożsamości religijnej młodzieży zaolziańskiej oraz będących odpowiedzią na potrzeby współczesnej młodzieży i wychodzeniem im naprzeciw.

Celem artykułu jest pokazanie Śląskiego Kościoła Ewangelickiego Augsburskiego Wyznania jako instytucji znaczącej w kształtowaniu otwartej tożsamości religijnej młodzieży uczącej się w polskich szkołach na Zaolziu. Przedstawione zostały wybrane działania edukacyjne Kościoła, zwłaszcza te będące próbami twórczego współdziałania ekumenicznego z innymi Kościołami.

Słowa kluczowe: działalność edukacyjna, Śląski Kościół Ewangelicko-Augsburski, Zaolzie, otwarta tożsamość religijna, współpraca ekumeniczna między Kościołami

\section{Wprowadzenie}

Nowoczesne społeczeństwo pluralistyczne przechodzi proces ustawicznych przekształceń i zmian. Społeczeństwo jest w ciągłym ruchu, a jego rozwój jest

1 T. Halík: Wzywany czy niewzywany, Bóg się tutaj zjawi. Europejskie wykłady z filozofii i socjologii dziejów chrześcijaństwa. Kraków 2006, Wydawnictwo WAM, s. 281. 
ciągłą zmianą, dostosowywaniem się do nowego i uczeniem się tego, czego w przeszłości nie było, do czego nie można się odnieść poprzez obowiązujące wzorce, ideały czy normy. Przyszłość okazuje się wielką niewiadomą, sprawą otwartą, nieokreśloną i mało przewidywalną. Można do niej podchodzić z dużą dozą obawy i niepewności bądź - akceptując różnorodność i ideę zmiany - przyjmować ją w postawie otwartości na novum w różnych obszarach życia społecznego² ${ }^{2}$ Przykładem społeczności poniekąd bardziej przygotowanych do zachodzących współcześnie zmian - z uwagi na wielokulturowość i pluralizm wpisane w ich losy historyczne - są wielokulturowe społeczności pograniczy. Na tych obszarach historycznie, w sposób naturalny, powstało i ustaliło się zjawisko pluralizmu religijnego. W zróżnicowanie kulturowe społeczności pograniczy wkomponowane jest zazwyczaj zróżnicowanie religijne (wyznaniowe), a religijność mieszkańców należących do różnych grup wyznaniowych i Kościołów przybiera tu szczególny charakter i wymiar. Społeczności wyznaniowe od dawna zamieszkujące te tereny odróżniają się - w swych wzajemnych relacjach, sposobach rozumienia się i praktycznym działaniu - od społeczności pozostałych, homogenicznych obszarów, realizując bardziej pozytywne wzory wzajemnych odniesień, poszanowania i współpracy. Mogą zatem być postrzegane jako specyficzne „laboratoria społeczne” działań, w tym oświatowych i edukacyjnych, które warunkowane są pluralizmem religijnym ${ }^{3}$. Można tu dostrzec zarówno odmienności wyznaniowe, ale i - poprzez zacieranie się różnic - podobieństwa w sferze życia duchowego i w codziennym funkcjonowaniu różnych grup wyznaniowych czy ich przedstawicieli. Bezpośrednie kontakty i relacje międzyludzkie stwarzają szanse wzajemnego poznania, zrozumienia i akceptacji

2 J. Mariański: Indywidualizacja religijna jako mega trend kulturowy. W: J. Kojkoł, B. Guzowska, R. Wójtowicz (red.): Społeczeństwo - kultura - religia. Gdynia 2015, Wydawnictwo Akademickie AMW, s. 163.

3 Pluralizm religijny rozumiem za Hansem-Georgem Ziebertzem i Jamesem Beckfordem nie tylko jako zróżnicowanie religijne, ale sposób radzenia sobie z tą wielością, poprzez postrzeganie zróżnicowania religijnego jako pożądanego, pokojowego współistnienia odrębnych wspólnot religijnych. Jest to rozumienie pluralizmu religijnego jako wartości, podtrzymującej ład społeczny, wynikającej z pokojowego współistnienia, ze wzajemnych kontaktów i współpracy różnych wspólnot religijnych na danym obszarze oraz spotkań osób różnych religii i kultur. Zob. H.-G. Ziebertz: Religijność $i$ wychowanie w świecie pluralistycznym. Kraków 2001, Wydawnictwo WAM, s. 15; J. Beckford: Teoria społeczna a religia. Kraków 2006, Zakład Wydawniczy „Nomos”, s. 121. 
Inności wyznaniowej, co daje większe niż gdzie indziej możliwości współdziałania i współpracy.

W sytuacji krzyżujących się oddziaływań społecznych pewną specyfiką odznaczają się również działania edukacyjne tradycyjnych instytucji wychowawczych, jakimi są rodzina, szkoła i Kościół. Instytucje te, w odpowiedzi na różnorodność kulturową i wyznaniową swoich adresatów, ale również zróżnicowanie ich postaw wobec religii oraz specyficznych potrzeb uwarunkowanych pluralistycznym środowiskiem, muszą uwzględniać wymienione odmienności kulturowe w programach działań edukacyjnych. Szkoły, instytucje oświatowe, jak też Kościoły i stowarzyszenia wyznaniowe w regionach wielowyznaniowych zadają sobie pytanie: Jak wielość i różnorodność kulturową (wyznaniową) uczynić wspólnym bogactwem? Formami profilaktyki przeciw zagrożeniom, jakie rodzi czasem odmienność kulturowa, w tym różnice wyznaniowe: przeciw nieracjonalnym podziałom, uprzedzeniom, a nawet przeciwko agresji, mogą być wzajemne poznanie, współpraca i współdziałanie ludzi odmiennych wyznań i religii.

Przykładem wielokulturowego pogranicza stanowiącego przestrzeń krzyżowania się odmiennych etnicznie i językowo, ale również zróżnicowanych religijnie i światopoglądowo grup i jednostek, jest Zaolzie - część Śląska Cieszyńskiego należącego do Republiki Czeskiej. Przedmiotem niniejszych rozważań jest działający w tym regionie Kościół luterański - Śląski Kościół Ewangelicki Augsburskiego Wyznania ${ }^{4}$, a w szczególności jego najnowsza edukacyjna działalność - w kontekście jej celów i zadań, odnoszących się do wspomagania kształtowania tożsamości religijnej młodzieży zaolziańskiej oraz będących odpowiedzią na potrzeby współczesnej młodzieży i wychodzeniem im naprzeciw. Celem niniejszego artykułu jest wskazanie Śląskiego Kościoła Ewangelickiego Augsburskiego Wyznania jako instytucji znaczącej w kształtowaniu otwartej tożsamości religijnej młodzieży uczącej się w polskich szkołach na Zaolziu, w Republice Czeskiej. U podstaw rozważań przyjęto tezę, że Kościół ewangelicki, z racji swego bezpośredniego (poprzez szkolną i parafialną edukację religijną), jak i pośredniego (przez różnorakie

4 Śląski Kościół Ewangelicki Augsburskiego Wyznania w Republice Czeskiej należy do grupy Kościołów luterańskich. Kościół zaistniał jako odrębna instytucja w roku 1920, po podziale Śląska Cieszyńskiego na dwie części - polską i czeską. Wówczas to Polacy ewangelicy na Zaolziu, ze względu na niespełnienie oczekiwań powrotu do Macierzy, nie mogli dalej należeć do macierzystego Kościoła ewangelickiego w Polsce i zmuszeni byli utworzyć odrębną instytucję kościelną. 
formy wspólnotowego i ekumenicznego wychowania młodzieży, działalność kulturalno-oświatową, działalność edukacyjną w obszarze sztuki) oddziaływania na młodzież, pełni rolę duchowej podstawy kształtowania tożsamości religijnej młodzieży.

\section{Kształtowanie tożsamości religijnej}

Z uwagi na liczne kontrowersje dotyczące rozumienia pojęcia tożsamości, $\mathrm{w}$ tym tożsamości religijnej stosowanej w niniejszej pracy, niezbędne jest ustalenie istoty i zakresu znaczeniowego pojęcia. Tożsamość, powszechnie kojarzona z pytaniami: kim jestem? kim jesteśmy?, należy do grupy polisemicznych pojęć, które trudno jednoznacznie zdefiniować. Trudność wynika między innymi z tego, że jest to konstrukt złożony z różnorodnych zjawisk, do których się odnosi, oraz ze złożoności procesu autopercepcji jednostki i wizji własnej osoby, wówczas rozumiany jest jako zbiór wyobrażeń, sądów, uczuć i przekonań, które odnosi podmiot wobec siebie ${ }^{5}$. Z drugiej strony cechy te wynikają z przynależności i identyfikacji jednostki z określoną grupą/ grupami oraz z postrzegania jej i przypisania do określonych grup przez innych. W ten sposób wyróżnia się tożsamość indywidualną (osobistą) i społeczną, która ma zarówno wymiar subiektywny, określany jako poczucie tożsamości, jak i obiektywny, rozumiany jako zaklasyfikowanie jednostki przez innych ${ }^{6}$.

W niniejszym opracowaniu odnoszę się przede wszystkim do tożsamości religijnej, którą pojmuję jako „wieloaspektowy sposób rozumienia oraz kształtowania własnej egzystencji, a także otaczającej rzeczywistości przez pryzmat osobistego doświadczenia wiary i wspólnotowych sposobów jej wyrażania w obrzędach i przekazie, czyli religii, do której się przynależy"7.

5 Por. Z. Bokszański: Tożsamość - integracja - grupa. Łódź 1989, UŁ, s. 12.

6 M. Jarymowicz, T. Szustrowa: Poczucie własnej tożsamości - źródta i funkcje regulacyjne. W: J. Reykowski (red.): Osobowość a społeczne zachowanie się ludzi. Warszawa 1980, KiW, s. 124.

7 Por. A. Różańska: Ksztattowanie się tożsamości religijnej młodzieży w sytuacji pluralizmu kulturowego i religijnego. W: T. Lewowicki, B. Grabowska, A. Różańska (red.): Socjalizacja i kształtowanie się tożsamości - problemy i sugestie rozwiązań. Cieszyn - Warszawa - Toruń 2008, Wydział Etnologii i Nauk o Edukacji Uniwersytetu Śląskiego, Wyższa Szkoła Pedagogiczna ZNP w Warszawie, Wydawnictwo Adam Marszałek, s. 230. 
Tożsamość religijna współczesnego człowieka jest podporządkowana doświadczeniu wewnętrznemu jednostki oraz jej przekonaniom na temat rzeczywistości pozaempirycznej. Tworzą ją trzy podstawowe komponenty:

- emocjonalny - obejmuje wyuczone przez jednostkę reakcje na pozaempiryczne sacrum;

- kognitywny - dotyczy poznanych i opanowanych przez jednostkę sposobów myślenia i mówienia (granie roli), odpowiadających za rozpoznanie i określenie danej sytuacji jako przynależnej do sfery religijnej;

- behawioralny - odnosi się do kultu religijnego i obejmuje dopełnianie rytuałów, praktyk religijnych i prac na rzecz Kościoła ${ }^{8}$.

Tożsamość religijna, podobnie jak inne wymiary tożsamości, jest pojęciem relacyjnym. Kształtuje się w relacji do innych, do przeszłości, do kontekstu społecznego, a nawet do przyszłości.

Współczesne wielokulturowe społeczeństwa pluralistyczne - w których poszczególne jednostki/grupy o odmiennych tożsamościach religijnych chcą żyć razem, pokojowo i bezpiecznie - warunkują potrzebę kształtowania nowej, otwartej tożsamości religijnej - otwartej na Innych religijnie, na ich odmienność kulturową i religijną. Podstawą otwartej tożsamości religijnej jest poczucie własnej tożsamości religijnej, które umożliwia otwarcie się na Innych, przyswajanie ich kodów znaczeniowych, ułatwia dyfuzję kulturową i wzbogacenie własnej religijności o nowe aspekty, bez obawy rozmycia własnej tożsamości ${ }^{9}$, sprzyja też podejmowaniu jakże potrzebnych wspólnych działań.

Kształtowanie otwartej tożsamości religijnej jest kwestią istotną w środowiskach pluralistycznych, gdzie relacje między różnymi religiami mają nierzadko charakter konfrontacji międzygrupowych, a tożsamość tworzona jest na zasadzie porównywania i oceny „lepszości” i „wyższości” poszczególnych grup. W konsekwencji negatywnego postrzegania się i niewłaściwych relacji niektóre grupy (zwłaszcza mniejszościowe) mogą poczuć się zagrożone

8 Więcej na temat zobacz: H. Mielicka: Tożsamość indywidualna a tożsamość społeczna jako wymiar religijności. W: M. Libiszowska-Żółtkowska (red.): Tożsamości religijne w społeczeństwie polskim. Warszawa 2009, Difin, s. 22-27.

9 L. Dyczewski: Od tożsamości zamkniętej do otwartej w spoteczeństwie wielokulturowym i globalnym. W: T. Lewowicki, J. Urban, A. Szczypka Rusz (red.): Jezzk, komunikacja i edukacja w społecznościach wielokulturowych. Cieszyn - Warszawa 2004, UŚ - Filia w Cieszynie, Wyższa Szkoła Pedagogiczna ZNP w Warszawie, s. 60-61. 
i wykluczone przez inne (zwykle większościowe) ${ }^{10}$. Aby w społeczności pluralistycznej żadna grupa czy osoba nie czuła braku akceptacji ze względu na swoją Inność, należy kształtować własną tożsamość religijną nie w opozycji do Innego, lecz wobec Innego, przyjmując jego tożsamość za źródło dopełnienia i wzbogacenia własnej. Warunek ten dotyczy zwłaszcza ludzi młodych, którzy ze względu na wiek mogą przeżywać kryzys tożsamości religijnej, stąd akceptacja i uznanie środowiska rówieśniczego ma dla nich szczególne znaczenie. $Z$ drugiej jednak strony tożsamość (również religijna) traktowana jest jako refleksyjny „projekt do zrobienia“, za który odpowiedzialny jest jego twórca, który musi polegać przede wszystkim na swoich działaniach, wyborach i decyzjach, ponieważ to one "czynią nas tym, kim jesteśmy. Świat nowoczesny zmusza nas do odnajdywania siebie. Jako samoświadome jednostki ludzkie wciąż tworzymy i odtwarzamy naszą tożsamość"11. Kreowanie otwartej tożsamości religijnej najbardziej warunkują częste i pozytywne kontakty z osobami innych wyznań i religii, a zwłaszcza wspólne działania - „projekty na rzecz wspólnego dobra" - ludzi różnych wyznań.

\section{Kościół wielokulturowego pogranicza}

Opisując działalność edukacyjną Śląskiego Kościoła Ewangelickiego Augsburskiego Wyznania (ŚKEAW), należy rozważać ją w relacji do regionu, który swoim zasięgiem obejmuje, oraz żyjących tam społeczności. Regionem tym jest Zaolzie, czyli czeska część Śląska Cieszyńskiego. Kościół funkcjonuje na pograniczu polsko-czeskim, w społeczeństwie wielokulturowym, wielonarodowym i wielowyznaniowym, ponadto w środowisku pluralistycznym z silnie zaznaczoną sekularyzacją.

Śląsk Cieszyński jest regionem Europy o bogatych tradycjach kulturowych łączących w sobie wpływy kultury polskiej, czeskiej, morawskiej i niemieckiej. Burzliwe są dzieje jego przynależności państwowej i powiązanych z nią stosunków narodowościowych. Szczególnie dotyczy to Zaolzia - etnicznie polskiego obszaru historycznego Księstwa Cieszyńskiego, przydzielonego na

10 Por. A. Różańska: Dynamika poczucia tożsamości religijnej młodzieży na pograniczu polsko-czeskim i jej edukacyjne uwarunkowania. W: H. Rusek, A. Pieńczak, J. Szczyrbowski (red.): Dziedzictwo kulturowe jako klucz do tożsamości pogranicza polsko-czeskiego. Cieszyn - Katowice - Brno 2010, Offsetdruk i media sp. z o.o., s. 248-263.

11 A. Giddens: Socjologia. Warszawa 2004, WN PWN, s. 53. 
mocy decyzji Rady Ambasadorów w 1920 roku Czechosłowacji. Występują tutaj wszystkie charakterystyczne cechy pogranicza terytorialnego i kulturowego. W XX wieku obszar ten siedmiokrotnie zmieniał przynależność państwową. Zmienne są też losy społeczności zamieszkujących ten region. Miejscowa ludność reprezentuje różne grupy etniczne, narodowościowe i wyznaniowe, jest nosicielami różnych wzorów kulturowych, postaw i systemów wartości. Polska grupa narodowościowa stanowiąca na przełomie XIX i XX wieku 80\% lokalnej ludności stanowi dziś niespełna 11\%. Swoje przetrwanie i utrzymanie polskości zawdzięcza przede wszystkim polskiemu szkolnictwu, oświacie i Kościołowi. Rola polskiego Kościoła (katolickiego i ewangelickiego) w utrzymaniu polskości na Zaolziu była znaczna w czasie intensywnej czechizacji w okresie międzywojennym, jak również po II wojnie światowej, w latach intensywnej ateizacji, w których władze komunistyczne realizowały wprawdzie model życia narodowościowego, lecz oderwanego od żywej kultury polskiej i wiary.

Działalność edukacyjna Kościołów - Kościoła rzymskokatolickiego i Kościoła ewangelickiego jako drugiego co do liczebności - osadzona jest w kontekście burzliwych dziejów i dokonań społeczności wyznaniowych i powinna być rozważana w kontekście różnorodnych uwarunkowań społeczno-historycznych, kulturowych i wyznaniowych, wyznaczających jej współczesny religijny i organizacyjny charakter.

Uwarunkowania społeczne wpłynęły na ukształtowanie się mniejszościowego charakteru Kościołów. Obecne zróżnicowanie religijne czeskiej części Śląska Cieszyńskiego należy postrzegać nie tylko jako współistnienie dwóch wyznań - rzymskokatolickiego i ewangelicko-augsburskiego - oraz kilkunastu innych ${ }^{12}$, pomniejszych, lecz analizować w kontekście znacznego zlaicyzowania społeczeństwa czeskiego, w tym również w regionie przygranicznym. Jest on terenem zamieszkiwanym przez liczną grupę osób nie związanych z żadnym Kościołem, często manifestacyjnie nazywających siebie ateistami. Przyczyn obecnego stanu rzeczy, kiedy to ponad połowę $(51,9 \%)$

12 Zarejestrowanymi Kościołami działającymi na Zaolziu są: Kościół rzymskokatolicki, Śląski Kościół Ewangelicki Augsburskiego Wyznania, Czeskobraterski Kościół Ewangelicki, Kościół Braterski, Kościół Adwentystów Dnia Siódmego, Kościół Apostolski, Luterański Kościół Ewangelicki, Jednota Braterska w Czechach, Ewangelicki Kościół Metodystów, Braterska Jednota Baptystów, Kościół Husycki i Związek Wyznania Świadków Jehowy. Ponadto na Śląsku Cieszyńskim po obu stronach Olzy istnieje szereg społeczności religijnych działających bez rejestracji, dystansujących się programowo od jakiejkolwiek konfesji. 
ludności okręgu morawsko-śląskiego stanowią bezwyznaniowi ${ }^{13}$, szukać należy w politycznych uwarunkowaniach życia społeczeństwa czeskiego, zwłaszcza w podporządkowaniu w przeszłości wszystkich jego wymiarów, w tym i religii, doktrynie komunistycznej oraz we wpływie ogólniejszych czynników wyznaczających współczesną postmodernistyczną rzeczywistość europejską. W okresie panowania reżimu komunistycznego życie religijne społeczności na Zaolziu było poddawane podobnym represjom, jak w całej Czechosłowacji. Konspiracyjna działalność wspólnot Kościoła podziemnego przebiegała tak w obrębie Kościoła katolickiego, jak i ewangelickiego. Niekiedy były to wspólne spotkania wierzących obu wyznań, zwłaszcza dotyczyło to spotkań młodzieży. Pozytywną spuścizną tych trudnych czasów jest stosunkowo duże w społeczności zaolziańskiej zrozumienie potrzeby działań ekumenicznych i współpracy ludzi różnych wyznań w wielu obszarach - nie tylko w religijnym - życia społecznego.

Zmiany zachodzące współcześnie w społeczeństwie ponowoczesnym pod wpływem czynników społecznych prowadzą m.in. do załamania tradycyjnego ładu społecznego, rozkładu międzypokoleniowych więzi społecznych w rodzinie, kwestionowania tradycji oraz osłabienia autorytetów, również autorytetu Kościoła ${ }^{14}$. Kierunek zmian religijności polega na przechodzeniu od „chrześcijaństwa z tradycji” do "chrześcijaństwa z wyboru” 15 , co w konsekwencji powoduje indywidualizację i różnorodność postaw. Uwzględniając jeden spośród wskaźników mówiących o globalnej postawie wobec wiary, a mianowicie autodeklarację wiary, można stwierdzić, że zróżnicowanie postaw wobec religii przejawia się głównie poprzez rozszerzenie się kategorii osób religijnie

13 Sčitání lidu, domů a bytů k 1.3.2001 - obyvatelstvo. Praha 2003. (Spis ludności w Republice Czeskiej w dniu 1.03.2001 - ludność). W skali ogólnokrajowej odsetek osób niewierzących w Republice Czeskiej jest jeszcze wyższy. Nie zostały uwzględnione dane ze spisu ludności z 2011 roku, ponieważ na nieobowiązkowe pytanie dotyczące przynależności wyznaniowej nie odpowiedziała prawie połowa $(45,2 \%)$ ankietowanych, co spowodowało, że dane dotyczące struktury wyznaniowej są zniekształcone i nie odzwierciedlają rzeczywistego stanu.

14 Por. W. Świątkiewicz: Tradycja i wybór. Socjologiczne studium religijności na Górnym Ślasku. Katowice - Wrocław 1997, Centrum Badań Śląskoznawczych i Bohemistycznych Uniwersytetu Wrocławskiego, Societas Scientiis Favendis Silesiae Superioris - Instytut Górnośląski, Oddział PAN w Katowicach, s. 66-67.

15 Tak przyjęło się określać wzory religijności będące wyrazem przekonania religijnego wynikającego nie tyle z tradycji, ile z mocy indywidualnego wyboru. Tamże, s. 197. 
obojętnych i niezdecydowanych w stosunku do wierzących. Dokonana przez młodzież zaolziańską samoidentyfikacja religijna pokazuje, iż 61,9\% młodzieży to osoby wierzące, wśród których 14,4\% to głęboko wierzące, dość spora liczba ankietowanych uznała siebie za niezdecydowanych - 26,3\% i niebagatelna grupa za obojętnych religijnie lub wręcz ateistów - 10,2\%.

Kościół ewangelicki na Zaolziu liczy aktualnie około 20 tysięcy członków zrzeszonych w 21 parafiach oraz 39 stacjach kaznodziejskich, które terytorialnie, za wyjątkiem dwu parafii - ostrawskiej i frydeckiej - pokrywają się z obszarem Zaolzia. Pod względem narodowościowym i językowym jest Kościołem czesko-polskim o przeważającej większości członków narodowości czeskiej ${ }^{16}$. Jakkolwiek Kościół nie jest w sytuacji diaspory w rozumieniu historycznym i terytorialnym, to analizując rzeczywistość społeczną, w której działa, należy mieć na uwadze jego diasporalny charakter. Jest Kościołem mniejszościowym w aspekcie religijnym, narodowościowym i społecznym. Mniejszościowy charakter Kościoła rzutuje na możliwości jego działalności społecznej, w tym również edukacyjnej, i wyznacza jego specyfikę wspólnotową i wychowawczą.

Sytuację chrześcijan zaolziańskich prawdziwie opisuje ogólniejsze zdanie wypowiedziane pod adresem chrześcijaństwa europejskiego: „Religia wprawdzie nie umarła - można powiedzieć, że chrześcijanie wydają się dzisiaj o wiele bardziej wiarygodni niż filozofowie wyrażający filozofię transcendentalną - ale chrześcijanie w Europie przyzwyczaili się do swego statusu poznawczej i etycznej mniejszości"17. Dodać można, że sytuacja mniejszościowa i diasporalna nie jest sytuacją ogólnie niesprzyjającą Kościołowi. Nie musi być zagrożeniem, lecz szansą społeczną i kulturową ${ }^{18}$, co zauważają duchowni ewangeliccy; co więcej, jest - w ich opinii - tą właściwą (bo aktywizującą) dla biblijnego świadectwa oraz jego głosicieli. Niemniej z szansy tej należy skorzystać, zwłaszcza w kontekście wysiłków edukacyjnych, w jak najszerszym zakresie, aby przygotować młode pokolenie do istniejących warunków rzeczywistości kulturowej i społecznej.

16 W przeszłości był Kościołem skupiającym przede wszystkim Polaków, jednak trend asymilacyjny spowodował istotne zmiany składu narodowościowego wiernych.

17 Z. Krasnodębski: Postmodernistyczne rozterki kultury. Warszawa 1996, Oficyna Naukowa, s. 180. Cyt. za: W. Świątkiewicz: Tradycja i wybór. Socjologiczne studium religijności na Górnym Śląsku. cyt. wyd., s. 192.

18 Por. B. Milerski: Żyć $w$ diasporze... Zagrożenia i szanse w kontekście polskiego protestantyzmu. „Myśl Protestancka” 2002, nr 1, s. 4-5. 


\section{Nowe potrzeby młodego pokolenia - nowe cele i sposoby działania}

Jedną z istotnych cech współczesnego życia jest jego postępująca sekularyzacja $^{19}$ i desakralizacja. Kultura ulega nieustającym przemianom, a człowiek w niej żyjący poszukuje coraz to innych słów, idei, znaczeń i wartości, gubiąc nierzadko po drodze rzeczywistość świata, siebie samego i Boga. Ale nawet ta najbardziej zdesakralizowana egzystencja nosi ślady religijnej waloryzacji świata ${ }^{20}$ i nie zatraciła duchowego i transcendentnego wymiaru, co przejawia się w różnych poszukiwaniach religijnych młodego pokolenia i potrzebie odnowy poczucia sacrum. Stąd jedną z istotnych potrzeb młodych ludzi jest wspomaganie ich w kształtowaniu otwartej tożsamości religijnej, w kształtowaniu umiejętności dokonywania wyborów w sferze kwestii etycznych, egzystencjalnych i społecznych oraz gotowości podejmowania dialogu z ludźmi o innych przekonaniach światopoglądowych, innych wyznań i religii.

Kościół ewangelicki na Zaolziu, podobnie jak inne Kościoły, próbuje uwzględnić aktualną sytuację życia młodego pokolenia z charakterystyczną dla niej zmianą religijności i tożsamości religijnej. Usiłuje przyjąć nową perspektywę pedagogii, teorii i praktyki edukacyjnej Kościoła: rzeczywiste potrzeby współczesnej młodzieży i wychodzenie im naprzeciw. Projektując aktualną działalność edukacyjną, usiłuje wyrażać ją w nowych środkach, formach i metodach. Zarówno formy wychowawczej działalności wspólnotowej, jak i szkolnej edukacji religijnej realizowanej według modelu konfesyjno-dialogicznego (otwartego), świadczą o trosce, jaką objęta jest - refleksyjna, afirmacyjna i krytyczna zarazem - edukacja religijna młodzieży. Należy jednak ubolewać, że na naukę religii jako nieobowiązkowy przedmiot uczęszcza znikomy - około 5\% - odsetek młodzieży. Pozytywnym aspektem tego jest, że w sytuacji, kiedy w danej szkole uczniów chcących uczęszczać na lekcje religii nie jest zbyt dużo, ze względów praktycznych łatwiej utworzyć grupę z uczniów różnych wyznań, ekumeniczną, co czynią zazwyczaj Kościoły protestanckie.

19 Sekularyzacja, najogólniej ujmując, oznacza autonomię sfery doczesnej od sakralnej i wyraża się w rozdziale Kościoła od państwa. Istotny jest jednak jej wpływ na kulturę i życie społeczne przejawiający się w desakralizacji, czyli w zanikaniu treści religijnych w sztuce, literaturze i świadomości ludzi, a co za tym idzie, w innym rozumieniu świata.

20 M. Eliade: Sacrum, mit, historia. Warszawa 1974, PIW, s. 27. 


\section{Wspólnotowe i międzywspólnotowe wychowanie młodzieży}

Różnymi formami katechizacji objętych jest ponad 3000 dzieci i młodzieży, z tego tylko trzecia część katechizacją szkolną. W latach 2000-2013 miała miejsce w ponad 70 szkołach i brało w niej udział od 1000-1100 dzieci. Nauka religii w szkole w Republice Czeskiej ma - w odróżnieniu od Polski - charakter zajęć nadobowiązkowych. Dlatego edukacja chrześcijańska realizowana jest przede wszystkim na terenie parafii oraz w coraz większej mierze na płaszczyznach współpracy międzywyznaniowej. Wychowawcami i twórcami działań edukacyjnych są nie tylko nauczyciele i katecheci, ale cała wspólnota religijna - począwszy od rodziny, nauczycieli, organizatorów działań wychowawczo-opiekuńczych, animatorów życia kulturalno-oświatowego, a na kolegach kończąc. Świeccy pracownicy odpowiedzialni za różnorodne formy działań stanowią ponad 80\% ogółu zaangażowanych w działalności edukacyjnej Kościoła. Kościół jako wspólnota jest podstawowym ośrodkiem wychowawczym, nie uważa jednak siebie za jedyną płaszczyznę edukacji religijnej. W swych działaniach uwzględnia równoległość edukacji rodzinnej, wspólnotowej, szkolnej i środowiskowej.

Tabela 1. Wspólnotowa katechizacja i wychowanie młodzieży

\begin{tabular}{|l|l|}
\hline \multicolumn{1}{|c|}{ Forma organizacyjna } & \multicolumn{1}{c|}{ Liczba grup } \\
\hline szkółki niedzielne & 50 \\
\hline nauka konfirmacyjna & 21 \\
\hline młodzież pokonfirmacyjna & 18 \\
\hline młodzież starsza & 17 \\
\hline kluby dziecięcej misji osiedlowej & 15 \\
\hline letnie kolonie dzieci i młodzieży & $20-30$ \\
\hline konferencje, kluby młodzieżowe w ramach projektu M.I.S.E & różna liczba \\
\hline spotkania małżeństw & 18 \\
\hline grupy i kluby dyskusyjne & $15-20$ \\
\hline nabożeństwa młodzieżowe & $30-40$ \\
\hline kluby i kółka zainteresowań w parafiach & $10-20$ \\
\hline praca Stowarzyszenia Benjamin z młodzieżą trudną & 5 \\
\hline ekumeniczne kolonie dla dzieci & kilka turnusów \\
\hline obozy wędrowne & corocznie, 4 turnusy \\
\hline konkursy biblijne, poetyckie, ekumeniczne, plastyczne, ekologiczne & corocznie \\
\hline $\begin{array}{l}\text { kursy: języka angielskiego, języka migowego, gry na instrumentach perkusyj- } \\
\text { nych }\end{array}$ & $\begin{array}{l}\text { wóża liczba grup } \\
\text { latach }\end{array}$ \\
\hline
\end{tabular}


cd. tabeli 1

\begin{tabular}{|l|l|}
\hline $\begin{array}{l}\text { korespondencyjne kursy dla dzieci organizowane przez stowarzyszenie Dětská } \\
\text { misie/Misja wśród Dzieci }\end{array}$ & \\
\hline olimpiady i turnieje sportowe & corocznie \\
\hline wycieczki krajoznawcze & $\begin{array}{l}\text { różna liczba } \\
\text { w poszczególnych } \\
\text { parafiach }\end{array}$ \\
\hline
\end{tabular}

Źródło: opracowanie własne na podstawie sprawozdań rocznych ŚKEAW z lat 2006-2014, http://www.sceav.cz/index.php/pl/dokumenty-i-materialy (27.04.2015)

Parafialne formy działalności edukacyjnej Kościoła - dzięki aktywnemu uczestnictwu i poczuciu sprawstwa młodzieży - są bardziej efektywne niż szkolne formy katechezy. Również młodzież wskazała na formy katechezy parafialnej jako na formy ciekawsze i chętniej uczęszczane (89\% respondentów). Uczestnictwo młodzieży w tej wielostronnej aktywności jest czynne - 38\% $\mathrm{z}$ nich partycypuje w przygotowaniu i realizacji programu według wcześniej deklarowanych potrzeb.

Formy i metody oddziaływania zależą w głównej mierze od inicjatywy (zaangażowanych etatowo bądź społecznie) pracowników, od samej młodzieży, jak również od sytuacji społecznej i możliwości personalnych oraz finansowych Kościoła i jego organizacji.

\section{Budowanie otwartej tożsamości religijnej poprzez współpracę ekumeniczną}

Jak wcześniej przedstawiono, otwartą tożsamość religijną warunkują rodzaj i częstość kontaktów z osobami innych wyznań i religii, a zwłaszcza wspólne działania ludzi różnych wyznań. Są one pomocne w nabywaniu pozytywnych postawy wobec Innych religijnie, a nawet w zawieraniu przyjaźni.

Obecność chrześcijan w różnych obszarach życia społecznego jest niezbędna i bezdyskusyjna, gdyż wynika z chrześcijańskiego podłoża kultury i cywilizacji europejskiej. Natomiast obecność ta nie tyle powinna prowadzić do jakiegoś podkreślania swojej odrębności, ale do twórczego odkrywania jedności, czego szczególnym wyrazem jest ekumenia. Duch ekumeniczny ukazuje możliwości budowania jedności wśród ludzi, którzy czerpią inspirację z Objawienia ${ }^{21}$. Może to mieć znaczenie zarówno dla pracy wychowaw-

21 Por. M. Nowak: Uniwersalizująca i integrująca rola chrześcijaństwa $w$ spoteczeństwie pluralistycznym. W: T. Lewowicki, A. Różańska, U. Klajmon (red.): Kwestie 
czej wśród chrześcijan, jak również jako wspólne świadectwo chrześcijan dla innych - zgodnie z ewangelijnym przesłaniem: „poznacie ich po ich owo-

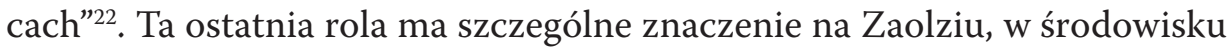
zsekularyzowanym i laickim.

Model współpracy ekumenicznej - nazywany modelem „jedności w pojednanej różnorodności" - jest realizowany w Kościele ewangelickim na Zaolziu przede wszystkim poprzez młodzieżowe formy działań:

- spotkania młodzieży różnych wyznań (spotkania ogólnokościelne, ale też lokalne, parafialne);

- Ekumeniczne Dni Biblii w Karwinie-Frysztacie;

- Tydzień Modlitw o Jedność Chrześcijan w styczniu każdego roku, praktykowany w poszczególnych parafiach;

- letnie obozy młodzieżowe i spotkania ewangelizacyjne XcamP w Śmiłowicach, skupiające corocznie od 300-500 uczestników. Inicjatywa ta rozpoczęła się w 1989 roku w Toszonowicach, w 2001 roku została przeniesiona do Śmiłowic koło Ligotki Kameralnej, w 2007 roku przyjęła nazwę XcamP, nawiązując do starochrześcijańskiego monogramu greckiego zapisu słowa Chrystus. Obóz ma charakter festiwalu ewangelizacyjnego, gdzie poza wykładami, seminariami i ewangelizacjami proponowana jest szeroka oferta warsztatów praktycznych, artystycznych, koncertów i aktywności sportowych ${ }^{23}$. Uczestniczy w nim młodzież różnych wyznań z Republiki Czeskiej, Słowacji i Polski;

- wakacyjne Zjazdy Młodzieży Studiującej „SAM” (Sjezd alternativní mládeže - Zjazd Alternatywnej Młodzieży) w Orłowej, coroczne od 1999 roku nietypowe spotkania młodzieży różnych wyznań, poszukującej, „alternatywnej” w sensie wyboru innego, alternatywnego wobec konsumpcyjnego, stylu życia. Bierze w nich udział około 120 młodych ludzi, uczniów szkół średnich i studentów ${ }^{24}$. Zjazdy SAM-u dostarczają różne formy aktywności duchowej, znane są też z bogatej oferty artystycznej (wieczorne koncerty, teatry, filmy);

- Młodzieżowe Ewangelizacje w Dzięgielowie (organizowane przez Kościół Ewangelicko-Augsburski w Polsce), w których od początków ich

wyznaniowe w społecznościach wielokulturowych. Cieszyn 2002, UŚ - Filia w Cieszynie, s. 375.

22 Mt 7, 20.

23 Szerzej zobacz: http://www.xcamp.cz (25.04.2015).

24 Szerzej zobacz: http://www.samorlova.cz (27.04.2015). 
istnienia, tzn. od lat 60. XX wieku, a zwłaszcza po uzyskaniu wolności w 1990 roku, uczestniczy młodzież z Zaolzia;

- Chrześcijańska Akademia Młodych (Křestanská akademie mladých) międzywyznaniowa organizacja chrześcijańska, kierująca różnorodne formy działań edukacyjnych do młodej generacji, niezależnie od jej przynależności wyznaniowej. Jak podaje w swym statucie, istotą jej pracy jest promowanie jedności, nie podziałów, jedności, której podstawą jest Biblia i chrześcijaństwo wyrażane w różnoraki sposób ${ }^{25}$.

Społeczności lokalne różnych wyznań jawią się jako wspólnoty dialogiczne i dialogizujące. Kultura i religijność tych wspólnot wyrasta z pluralizmu kulturowego i religijnego osób ją tworzących. Zróżnicowanie to jest zachowane, ale ważność różnorodnych stanowisk i aktywności wynikająca z tego zróżnicowania jest odnoszona do zadań wyznaczanych przez zlaicyzowane środowisko lokalne, którego największą potrzebą jest obecność chrześcijańskich wartości, norm i zasad postępowania, która może być bardziej zauważalna poprzez wspólne działania społeczne manifestujące jedność chrześcijan różnych wyznań.

\section{Bibliografia}

Beckford J.: Teoria społeczna a religia. Kraków 2006, Zakład Wydawniczy „Nomos".

Bokszański Z.: Tożsamość - integracja - grupa. Łódź 1989, UŁ.

Dyczewski L.: Od tożsamości zamkniętej do otwartej w społeczeństwie wielokulturowym i globalnym. W: T. Lewowicki, J. Urban, A. Szczypka Rusz (red.): Język, komunikacja i edukacja w społecznościach wielokulturowych. Cieszyn - Warszawa 2004, UŚ - Filia w Cieszynie, Wyższa Szkoła Pedagogiczna ZNP w Warszawie.

Eliade M.: Sacrum, mit, historia. Warszawa 1974, PIW.

Giddens A.: Socjologia. Warszawa 2004, WN PWN.

Halík T.: Wzywany czy niewzywany, Bóg się tutaj zjawi. Europejskie wykłady z filozofii i socjologii dziejów chrześcijaństwa. Kraków 2006, Wydawnictwo WAM. Jarymowicz M., Szustrowa T.: Poczucie własnej tożsamości - źródła i funkcje regulacyjne. W: J. Reykowski (red.): Osobowość a społeczne zachowanie sie ludzi. Warszawa 1980, KiW.

25 http://www.kam.cz (27.04.2015). 
Krasnodębski Z.: Postmodernistyczne rozterki kultury. Warszawa 1996, Oficyna Naukowa.

Mariański J.: Indywidualizacja religijna jako mega trend kulturowy. W: J. Kojkoł, B. Guzowska, R. Wójtowicz (red.): Społeczeństwo - kultura - religia. Gdynia 2015, Wydawnictwo Akademickie AMW.

Mielicka H.: Tożsamość indywidualna a tożsamość spoteczna jako wymiar religijności. W: M. Libiszowska-Żółtkowska (red.): Tożsamości religijne w społeczeństwie polskim. Warszawa 2009, Difin.

Milerski B.: Żyć w diasporze... Zagrożenia i szanse w kontekście polskiego protestantyzmu. „Myśl Protestancka” 2002, nr 1.

Nowak M.: Uniwersalizujaca i integrująca rola chrześcijaństwa w społeczeństwie pluralistycznym. W: T. Lewowicki, A. Różańska, U. Klajmon (red.): Kwestie wyznaniowe w społecznościach wielokulturowych. Cieszyn 2002, UŚ - Filia w Cieszynie.

Różańska A.: Dynamika poczucia tożsamości religijnej młodzieży na pograniczu polsko-czeskim i jej edukacyjne uwarunkowania. W: Rusek H., Pieńczak A., Szczyrbowski J. (red.): Dziedzictwo kulturowe jako klucz do tożsamości pogranicza polsko-czeskiego. Cieszyn - Katowice - Brno 2010, Offsetdruk i media sp. z o.o.

Różańska A.: Kształtowanie się tożsamości religijnej młodzieży w sytuacji pluralizmu kulturowego i religijnego. W: T. Lewowicki, B. Grabowska, A. Różańska (red.): Socjalizacja i kształtowanie się tożsamości - problemy i sugestie rozwiazań. Cieszyn - Warszawa - Toruń 2008, Wydział Etnologii i Nauk o Edukacji Uniwersytetu Śląskiego, Wyższa Szkoła Pedagogiczna ZNP w Warszawie, Wydawnictwo Adam Marszałek.

Sčitání lidu, domů a bytio k 1.3.2001 - obyvatelstvo. Praha 2003. (Spis ludności w Republice Czeskiej w dniu 1.03.2001 - ludność).

Świątkiewicz W.: Tradycja i wybór. Socjologiczne studium religijności na Górnym Śląsku. Katowice - Wrocław 1997, Centrum Badań Śląskoznawczych i Bohemistycznych Uniwersytetu Wrocławskiego, Societas Scientiis Favendis Silesiae Superioris - Instytut Górnośląski, Oddział PAN w Katowicach.

Ziebertz H.-G.: Religijność $i$ wychowanie w świecie pluralistycznym. Kraków 2001, Wydawnictwo WAM. 


\section{Contribution of the Evangelical Church to the forming of open religious identity of youth from Zaolzie}

\section{Summary}

This study is an attempt to view educational activities of the Silesian Evangelical Church of Augsburg Confession in Zaolzie in the Czech Republic - in the context of its tasks related to enhancing religious identity forming of youth from Zaolzie, as well as the tasks which fulfill the needs of contemporary youth.

The aim of the study is to present the Silesian Evangelical Church of Augsburg Confession as an important institution which creates open religious identity of the youth attending Polish schools in Zaolzie. What is also presented here are some selected educational activities of the Evangelical Church, especially the activities which aim at creative ecumenical cooperation between various churches.

Key words: educational activities, the Silesian Evangelical Church of Augsburg Confession, Zaolzie, open religious identity, ecumenical cooperation between churches 